\title{
Clustering of Corporate Social Responsibility in the Indonesian Manufacturing Industry: How Far Can You Go?
}

\author{
Esti Dwi Rinawiyanti ${ }^{1, *}$ Xueli Huang ${ }^{2,} \&$ Sharif As-Saber ${ }^{3}$
}

\author{
${ }^{1}$ University of Surabaya, Surabaya, Indonesia \\ ${ }^{2}$ RMIT University, Melbourne, Australia \\ ${ }^{3}$ RMIT University, Melbourne, Australia \\ *Corresponding author.Email: estidwi@staff.ubaya.ac.id
}

\begin{abstract}
This paper aims to cluster corporate social responsibility (CSR) practices that correspond to the CSR strategy implemented. This study performed factor and cluster analyses with 435 data from Indonesian manufacturing companies. The factor analysis resulted three categories of CSR dimensions: legal-ethical, philanthropic, and economic responsibilities. The cluster analysis generated three clusters of CSR strategy: reactive, proactive, and accommodative. The results show that most manufacturing companies in Indonesia apply proactive strategy rather than reactive or accommodative strategies.
\end{abstract}

Keywords: corporate social responsibility, reactive, proactive, and accommodative.

\section{INTRODUCTION}

Over the past two decades, the concept of corporate social responsibility (CSR) has grown in popularity (Malik 2015) and has become a concern for businesses (Martinuzzi \& Krumay 2013), as they attempt to comply and gain advantages from it (Razafindrambinina \& Sabran 2014). However, the majority of CSR research focuses on CSR practices in developed countries (Zhu et al. 2016). Because CSR is emerging as a distinct area of management studies in developing countries (Jamali \& Karam 2018), it is essential to identify significant information on the contribution of CSR and the main factors affecting CSR performance (Branco \& Rodrigues 2006, Crifo et al. 2016), including in Indonesia.

More specifically, the Indonesian government has released Law No. 402007 on Limited Liability Companies (or UndangUndang (UU) No. 40 Tahun 2007 tentang
Perseroan Terbatas). With this law, Indonesia is the world's first country to mandate that companies, especially those related to natural resources, must implement CSR and report their CSR activities (Sheehy \& Damayanti 2019).

Several studies have investigated CSR implementation in the Indonesian manufacturing industry. For example, with a sample of 53 manufacturing companies, Hasanudin \& Budianto (2013) found that employee CSR and corporate reputation have a positive impact on company performance. Purbowati \& Mutiarni (2017) with a sample of 50 listed manufacturing companies argued that the company size has a significant impact on the CSR report, while the company's profile, the size of the commissioner board, and ownership concentration have no impact. Then, with survey data from 173 manufacturing companies, Handayani et al. (2017) highlighted the significant influence of CSR on company performance. 
However, little research has been conducted on how far Indonesian manufacturing companies go with CSR, particularly after 13 years of CSR regulation. Thus, this study aims to explore the extent to which they implement CSR to address the two research questions (RQ):

RQ1: Which dimension of CSR is most commonly implemented by the Indonesian manufacturing companies?

RQ2: Which CSR strategy is most widely applied by the Indonesian manufacturing companies?

\subsection{CSR Definition}

The World Business Council for Sustainable Development considered economic, ethical and social factors and declared CSR to be a continuous business agreement to act ethically and benefit from sustainable economic development while also improving the quality of life of employees, their families, the local community, and society at large (Moir 2001). Dahlsrud (2008) identified 37 different meanings of CSR in 27 studies between 1980 and 2003. The five most commonly used dimensions of CSR, according to the results of this study, are economic, social, environmental, stakeholder, and voluntary. Indeed, CSR can be defined using many terms, all of which express common sense with regards to the activities, relationships and responsibilities of companies to and with society (Branco \& Rodrigues 2006).

\subsection{CSR Dimensions}

Carroll $(1979,1991)$ proposed that CSR can be viewed from four perspectives: economic responsibilities. Business has traditionally been conceptualised as an economic entity with a responsibility to produce and provide goods and services as efficiently as possible, while making an acceptable profit (Carroll 1991). Legal responsibilities. Businesses are required to follow the laws and regulations enacted by the federal, state, and local governments as the ground rules for their operations (Carroll 1991). Ethical responsibilities. Ethical responsibilities embody the standards, norms, or expectations that reflect a concern for what customers, employees, shareholders and the community regard as fair, just, or in keeping with the respect or protection of the stakeholders' moral rights (Carroll 1991). Philanthropic responsibilities or discretionary responsibilities. Philanthropy encompasses corporate actions undertaken in response to society's expectations that businesses be good corporate citizens. Philanthropy is discretionary or voluntary despite societal expectations that businesses Philanthropy refers to the behaviour taken by corporations in response to society's expectations that they be responsible corporate citizens. Despite societal expectations that companies give back, philanthropy is discretionary or voluntary (Carroll 1991).

Carroll's definition of CSR has been one of the most accepted and widely used definitions of CSR in academic research (Dhanesh 2014) and is recognised as comprehensive and integrative by numerous theorists and empirical researchers (Wang \& Berens 2015).

\subsection{CSR Strategy}

A CSR strategy can bring together a variety of philanthropic, supply chain, and systemlevel programs under one umbrella (Rangan et al. 2012). Four types of CSR strategy (Wood 2010) can be used to explain how companies respond to their responsibilities: reactive. Companies implement reactive strategy if they apply CSR at the basic level required to meet their regulatory compliance (Torugsa et al. 2013). Defensive. Companies that apply a defensive strategy reject their ethical responsibilities and protect their interests within the legal framework (Ganescu 2012). Accommodative. Companies adopt the accommodative strategy by supporting certain ethical responsibilities, particularly those of their stakeholders, without initiating voluntary actions for the common good (Ganescu 2012). Proactive. Companies that apply the proactive strategy can actively manage the sustainability of economic, social and environment efforts, and support their CSR activities (Wagner et al. 2009) beyond the compliance (Torugsa et al. 2013). 


\section{RESEARCH METHODS}

\subsection{Measurements of CSR}

Table 1 shows 20 items from Maignan and Ferrell (2001) that can be used to measure CSR strategy on a five-point scale ranging from 1='strongly disagree' to $5=$ ='strongly agree'. These items were modified to represent current manufacturing condition in Indonesia so that respondents could understand them and gave an appropriate response.

Table 1. CSR Measurement Items

\begin{tabular}{ll}
\hline CSR Dimension \\
\hline Economic responsibility \\
CS01 & We aim to lower our operating costs. \\
CS02 & We closely monitor our employees' productivity. \\
CS03 & Top management develops long-term strategies. \\
CS04 & We handle any customer complaint according to a set of \\
guidelines. & We constantly improve the quality of our products. \\
Legal responsibility \\
CS06
\end{tabular} $\begin{aligned} & \text { Internal policies prevent discrimination in job compensation and } \\
& \text { promotion. } \\
& \text { CS07 }\end{aligned}$

\subsection{Sample and data collection}

This study used the 2017 Manufacturing Industrial Directory (BPS 2017) as the sampling framework that covered five areas in Java: Jakarta, West Java, Central Java, Yogyakarta and East Java. This study conducted a survey from June to October 2018 via post, personal delivery, and online. There were
1,055 questionnaires distributed, with 514 being returned. 435 responses persisted in the data set after data screening, representing a response rate of $41.23 \%$.

\section{RESULTS AND DISCUSSIONS}

\subsection{Factor Analysis of CSR Strategy}

Using SPSS 26, the first run of principal component analysis (PCA) resulted four cross-loading items that was deleted (CS03, CS04, CS05, and CS19). With 16 items remaining, the PCA was rerun and produced three factors with the total variance cumulative of $58.89 \%$ (see Table 2). The first factor relates to legal-ethical responsibility, the second factor refers to philanthropic responsibility, and the third factor refers to economic responsibility. Besides, Table 2 shows that the mean score of economic responsibility is similar to legal-ethical responsibility, assuming that respondents are more aware of those responsibilities than philanthropic responsibility that has the lowest mean score.

Table 2. Factor and Items of CSR Strategy

\begin{tabular}{llcl}
\hline \multirow{2}{*}{ Code } & \multicolumn{3}{c}{ Factor loading } \\
& F 1 & F 2 & F 3 \\
\hline CS06 & 0.57 & & \\
CS07 & 0.74 & & \\
CS08 & 0.75 & & \\
CS09 & 0.71 & & \\
CS10 & 0.70 & & \\
CS11 & 0.74 & & \\
CS12 & 0.70 & & \\
CS13 & 0.66 & & \\
CS14 & 0.71 & & \\
CS15 & 0.57 & & \\
CS16 & & 0.67 & \\
CS17 & & 0.75 & \\
CS18 & & 0.85 & \\
CS20 & & 0.77 & \\
CS01 & & & 0.88 \\
CS02 & & & 0.68 \\
\hline Mean & & & \\
Cronbach's alpha & & & \\
& & & \\
Sum of squared loadings & 6.60 & \\
(eigenvalue) & & & \\
\% of variance & & & \\
\hline
\end{tabular}




\subsection{Cluster Analysis of CSR Strategy}

Prior to cluster analysis, the different variables used for clustering are confirmed not to have substantial collinearity to avoid biasing the analysis (Hair et al. 2010). The results show that 16 items have the tolerance values between 0.44 and 0.81 and VIF values from 1.24 to 2.30. Thus, the result indicates the absence of collinearity (Hair et al. 2010). Cluster analysis of CSR strategy is employed using hierarchical and nonhierarchical clustering methods sequentially (Hair et al. 2010). The results of the hierarchical cluster from SPSS 26 identified a larger jump from two to three clusters (24.53\%) than from one to two clusters (22.17\%). Then, K-means clustering is conducted using three clusters (see Table 3).

Table 3. K-means CSR Strategy with Three Clusters

\begin{tabular}{cclll}
\hline \multirow{2}{*}{ Cluster } & $\begin{array}{c}\text { Number of } \\
\text { cases }\end{array}$ & \multicolumn{3}{c}{ Regression Score } \\
& 145 & -0.49 & -0.86 & 0.35 \\
2 & 180 & 0.18 & 0.76 & 0.47 \\
3 & 110 & 0.35 & -0.10 & -1.23 \\
\multirow{2}{*}{ ANOVA } & F & 31.25 & 204.93 & 232.75 \\
& Sig & 0.00 & 0.00 & 0.00 \\
\hline
\end{tabular}

Cluster one (145 respondents) has a belowaverage score for legal-ethical responsibility (factor 1) and philanthropy responsibility (factor 2), but an above-average score for economic responsibility (factor 3 ).

Cluster two (180 respondents) has an above-average score for all responsibilities (three factors), while the largest score lies with philanthropic responsibility (factor 2). Cluster three (110 respondents) has a belowaverage score for philanthropic responsibility (factor 2) and well-below-average score for economic responsibility (factor 3), but an above-average score for legal ethical responsibility (factor 1).

As shown in Table 3, $\mathrm{F}$ value and ANOVA results indicate that all factor scores are significant for three clusters. Based on the results, cluster one can be classified as a 'reactive' group that will fulfil their economic responsibilities while ignoring their legal, ethical and philanthropic responsibilities and rejecting any kind of social or ethical obligations that is not in their economic interest
(Lee 2011). Cluster two can be assumed to be a 'proactive' group which fully recognise their social responsibilities and actively strive to meet stakeholder needs and reduce negative effects of companies (Ganescu 2012). Cluster three can be regarded as an 'accommodative' group that conduct specific ethical responsibilities, particularly those related to stakeholders, and comply with legal requirements.

\subsection{Demography Characteristics of CSR Strategy Clusters}

Table 4 present the respondents characteristics in each cluster of CSR strategy. For most products, the number in cluster two (proactive) is more than other clusters, such as food and beverage, chemicals and chemical products, automotive, rubber and plastic products, tobacco and non-metallic mineral products. There are almost the same numbers for small companies, namely 15, 13, and 16 in cluster one, two, and three, respectively. The majority of medium companies adopt reactive strategy $(38.3 \%)$, followed by accommodative strategy $(35.1 \%)$ and proactive strategy $(26.6 \%)$. In contrast, almost half of large companies have proactive strategy $(47.8 \%)$, followed by reactive strategy $(31.7 \%)$ and accommodative strategy $(20.5 \%)$. This result is supported by other finding that proactive strategy in large companies are substantially higher than those among SMEs (Chang 2015).

Most respondents who have been running their business for five to 20 years are in cluster one, while cluster two dominates in terms of respondents operating over 20 years. There is slight equal number for respondents in each cluster who have been conducting their business for less than five years. This data reflects the ability of organizations to function in a range of CSR from reactive to proactive (Carroll 1979). Overall, based on the results, it can be assumed that most manufacturing companies in Indonesia apply proactive strategy rather than the other two strategies, reactive and accommodative. In- 
terestingly, there are still many companies that implement reactive strategy.

\section{CONCLUSION}

This study discovers that CSR practices related to legal-ethical responsibility and proactive strategy are most widely conducted by Indonesian manufacturing companies. The findings are consistent with the fact that manufacturing companies are affected by CSR regulation (Laws No. 40 in 2007). The results also indicate that the Indonesian manufacturing companies fulfil their four responsibilities; not only legal-ethical responsibility regarding the CSR regulation, but also philanthropic responsibility that beyond economic responsibility.

The findings of this study enrich CSR literature by elucidating the various CSR practices that help companies in conducting CSR and determining how far they can implement CSR, especially in the context of developing countries.

Table 4. Respondents Characteristics in Each Cluster of CSR Strategy

\begin{tabular}{|c|c|c|c|c|}
\hline Variable & $\begin{array}{l}\text { Cluster 1, } \\
\mathrm{n}=145 \\
\text { (Reactive) }\end{array}$ & $\begin{array}{l}\text { Cluster } \\
2, \mathrm{n}=180 \\
\text { (Proac- } \\
\text { tive) }\end{array}$ & $\begin{array}{l}\text { Cluster } 3 \text {, } \\
\mathrm{n}=110 \\
\text { (Accommoda- } \\
\text { tive) }\end{array}$ & $\begin{array}{l}\text { To- } \\
\text { tal }\end{array}$ \\
\hline \multicolumn{5}{|l|}{ Main product } \\
\hline $\begin{array}{l}\text { food and bever- } \\
\text { age }\end{array}$ & 39 & 42 & 34 & 115 \\
\hline tobacco & 1 & 6 & 4 & 11 \\
\hline textile & 8 & 10 & 11 & 29 \\
\hline $\begin{array}{l}\text { leather and } \\
\text { footwear }\end{array}$ & 2 & 4 & 2 & 8 \\
\hline $\begin{array}{l}\text { goods from } \\
\text { wood, handi- } \\
\text { craft }\end{array}$ & 4 & 0 & 1 & 5 \\
\hline paper & 14 & 8 & 3 & 25 \\
\hline $\begin{array}{l}\text { coke and re- } \\
\text { fined petroleum } \\
\text { products }\end{array}$ & 1 & 2 & 1 & 4 \\
\hline $\begin{array}{l}\text { chemicals and } \\
\text { chemical prod- } \\
\text { ucts }\end{array}$ & 12 & 26 & 10 & 48 \\
\hline $\begin{array}{l}\text { pharmaceuticals } \\
\text { and medicinal } \\
\text { chemical }\end{array}$ & 4 & 3 & 4 & 11 \\
\hline $\begin{array}{l}\text { rubber and plas- } \\
\text { tic products }\end{array}$ & 11 & 15 & 9 & 35 \\
\hline non-metallic & 6 & 12 & 3 & 21 \\
\hline
\end{tabular}

CONT.

\begin{tabular}{|c|c|c|c|c|}
\hline \multicolumn{5}{|l|}{$\begin{array}{l}\text { mineral prod- } \\
\text { ucts }\end{array}$} \\
\hline basic metals & 0 & 2 & 0 & 2 \\
\hline $\begin{array}{l}\text { fabricated metal } \\
\text { products, ex- } \\
\text { cepts machinery } \\
\text { and equipment }\end{array}$ & 17 & 15 & 10 & 42 \\
\hline $\begin{array}{l}\text { computers, } \\
\text { electronic and } \\
\text { optical products }\end{array}$ & 3 & 5 & 2 & 10 \\
\hline $\begin{array}{l}\text { machinery and } \\
\text { electrical } \\
\text { equipment }\end{array}$ & 6 & 8 & 6 & 20 \\
\hline automotive & 7 & 13 & 4 & 24 \\
\hline furniture & 8 & 5 & 4 & 17 \\
\hline $\begin{array}{l}\text { other manufac- } \\
\text { turing }\end{array}$ & 1 & 4 & 1 & 6 \\
\hline $\begin{array}{l}\text { repair and in- } \\
\text { stallation of } \\
\text { machinery and } \\
\text { equipment }\end{array}$ & 1 & 0 & 1 & 2 \\
\hline $\begin{array}{l}\text { Number of em- } \\
\text { ployees }\end{array}$ & & & & \\
\hline small & 15 & 13 & 16 & 44 \\
\hline medium & 36 & 25 & 33 & 94 \\
\hline large & 94 & 142 & 61 & 297 \\
\hline $\begin{array}{l}\text { Company's age } \\
\text { (years) }\end{array}$ & & & & \\
\hline$<5$ & 11 & 11 & 8 & 30 \\
\hline $5-10$ & 20 & 15 & 18 & 53 \\
\hline $11-20$ & 36 & 32 & 18 & 86 \\
\hline $21-50$ & 68 & 91 & 55 & 214 \\
\hline$>50$ & 10 & 31 & 11 & 52 \\
\hline $\begin{array}{l}\text { Company's lo- } \\
\text { cation }\end{array}$ & & & & \\
\hline East Java & 122 & 120 & 82 & 324 \\
\hline $\begin{array}{l}\text { Centre Java } \\
\& \text { Yogya- } \\
\text { karta }\end{array}$ & 6 & 17 & 6 & 29 \\
\hline $\begin{array}{l}\text { West Java \& } \\
\text { Jakarta }\end{array}$ & 17 & 43 & 22 & 82 \\
\hline
\end{tabular}

* The first author (EDR) would like to express her gratitude for the financial support provided by the Indonesian Endowment Fund for Education (LPDP), Ministry of Finance, in collaboration with the Directorate General of Higher Education (DIKTI), Ministry of Research, Technology and Higher Education, Republic of Indonesia.

\section{REFERENCES}

BPS. 2017. Direktori Industri Manufaktur 2017 (0216-0099). Retrieved from Jakarta, Indonesia: 
Branco, M.C. \& Rodrigues, L.L. 2006. Corporate Social Responsibility and Resource-Based Perspectives. Journal of Business Ethics 69(2): 111-132.

Carroll, A.B. 1991. The pyramid of corporate social responsibility: Toward the moral management of organizational stakeholders. Business Horizons 34(4): 39-48.

Chang, C.H. 2015. Proactive and reactive corporate social responsibility: antecedent and consequence. Management Decision 53(2), 451-468.

Crifo, P. Diaye, M.A. \& Pekovic, S. 2016. CSR related management practices and firm performance: An empirical analysis of the quantity-quality trade-off on French data. International Journal of Production Economics 171(3): 405-416.

Dahlsrud, A. 2008. How corporate social responsibility is defined: an analysis of 37 definitions. Corporate Social Responsibility and Environmental Management 15(1): 1-13.

Dhanesh, G.S. 2014. CSR as Organization-Employee Relationship Management Strategy: A Case Study of Socially Responsible Information Technology Companies in India. Management Communication Quarterly 28(1): 130-149.

Ganescu, M.C. 2012. Corporate social responsibility, a strategy to create and consolidate sustainable businesses. Theoretical and Applied Economics 11(576): 91-106.

Hair, J. Black, W. Babin, B. \& Anderson, R. 2010. Multivariate Data Analysis: A Global Perspective (Seventh ed.). Upper Saddle River, New Jersey: Pearson.

Handayani, R. Wahyudi, S. \& Suharnomo. 2017. The effects of corporate social responsibility on manufacturing industry performance: the mediating role of social collaboration and green innovation. Verslas : Teorija ir Praktika 18: 152-159.

Hasanudin, A.I. \& Budianto, R. 2013. The Implications of Corporate Social Responsibility and Firm Performance with Reputation as Intervening Variable Empirical Study in the Manufacturing Company in Indonesia. GSTF Journal on Business Review (GBR) 2(4): 106-109.

Jamali, D. \& Karam, C. 2018. Corporate Social Responsibility in Developing Countries as an Emerging Field of Study. International Journal of Management Reviews 20(1): 32-61.

Lee, M.D.P. 2011. Configuration of External Influences: The Combined Effects of Institutions and Stakeholders on Corporate Social Responsibility Strategies. Journal of Business Ethics 102(2): 281-298.

Maignan, I. \& Ferrell, O.C. 2001. Antecedents and benefits of corporate citizenship: an investigation of French businesses. Journal of Business Research 51(1): 37-51.

Malik, M. 2015. Value-Enhancing Capabilities of CSR: A Brief Review of Contemporary Literature. Journal of Business Ethics 127(2): 419-438.
Martinuzzi, A. \& Krumay, B. 2013. The Good, the Bad, and the Successful - How Corporate Social Responsibility Leads to Competitive Advantage and Organizational Transformation. Journal of Change Management 13(4): 424-443.

Moir, L. 2001. What do we mean by corporate social responsibility? Corporate Governance: The International Journal of Business in Society 1(2): 1622.

Purbowati, R. \& Mutiarni, R. 2017. Pengungkapan Corporate Social Responsibility Ditinjau dari Karakteristik Perusahaan. Jurnal Akuntansi dan Bisnis 3(2): 167-176.

Rangan, K. Chase, L. \& Karim, S. 2012. Why Every Company Needs a CSR Strategy and How to Build It: Harvard Business School.

Razafindrambinina, D. \& Sabran, A. 2014. The Impact of Strategic Corporate Social Responsibility on Operating Performance: An Investigation Using Data Envelopment Analysis in Indonesia. Journal of Business Studies Quarterly 6(1): 68-78.

Sheehy, B. \& Damayanti, C. 2019. Issues and Initiatives: Sustainability and Corporate Social Responsibility in Indonesia. The Cambridge Handbook of Corporate Law: Corporate Governance and Sustainability.

Torugsa, N. A. O'Donohue, W. \& Hecker, R. 2013. Proactive CSR: An Empirical Analysis of the Role of its Economic, Social and Environmental Dimensions on the Association between Capabilities and Performance. Journal of Business Ethics 115(2): 383-402.

Wagner, T. Lutz, R. J. \& Weitz, B.A. 2009. Corporate Hypocrisy: Overcoming the Threat of Inconsistent Corporate Social Responsibility Perceptions. Journal of Marketing 73(6): 77-91.

Wang, Y. \& Berens, G. 2015. The Impact of Four Types of Corporate Social Performance on Reputation and Financial Performance. Journal of Business Ethics 131(2): 337-359.

Wood, D.J. 2010. Measuring Corporate Social Performance: A Review. International Journal of Management Reviews 12(1): 50-84.

Zhu, Q. Liu, J. \& Lai, K.H. 2016. Corporate social responsibility practices and performance improvement among Chinese national state-owned enterprises. International Journal of Production Economics 171: 417-426. 